\section{A BIZONYTALANSÁGOK KORA FELÉRTÉKELHETI A KOCKÁZATOK SZÉTTERÍTÉSÉT INTERJÚ BOD PÉTER ÁKOSSAL}

Lambert Gábor (Magyar Biztositók Szövetsége), gaborlambert@mabisz.hu

\section{ÖSSZEFOGLALÓ}

Bod Péter Ákos a Budapesti Corvinus Egyetem egyetemi tanára, a Magyar Tudományos Akadémia doktora. 1975-ben szerzett közgazdasági diplomát Budapesten, kutatóintézetben dolgozott 1990-ig, mellette itthon és külföldi egyetemen tanított, ENSZ-tanácsadó volt a fejlődő világban. A rendszerváltozás után ipari és kereskedelmi miniszter, 1991 és 1994 között a Magyar Nemzeti Bank elnöke. 1995-1997 között a londoni EBRD igazgatótanácsának tagja, majd visszatért tanári pályájára. Számos szakkönyv, szakmai cikk szerzője, rendszeresen publikál gazdaságpolitikai kérdésekről. Nős, három gyermek apja.

\section{SUMMARY}

Péter Ákos Bod is professor at Corvinus University of Budapest, doctor of the Hungarian Academy of Sciences. Graduated in economics in Budapest, 1975, worked in economic research institute until 1990, and taught meanwhile in universities in Hungary and elsewhere, including the US, and was active as UN advisor in the developing world. Dr. Bod became cabinet minister for industry and trade after the transition, governor of the central bank between 1991 and 1994. He served on the board of EBRD, London between 1995 and 1997, then returned to academia and teaching. Author of several books, academic articles, and a frequent media contributor in economic policy issues. Married, with three children.

Kulcsszavak: Covid-19, világgazdaság Key words: Covid-19, world economics

JEL: E20, H12

DOI: $10.18530 /$ BK.2020.3-4.6

http://dx.doi.org/10.18530/BK.2020.3-4.6
A Világbank nemrégi előrejelzése szerint idén az országok 93 százaléka lesz recesszióban, míg 2008-ban csak hatvanegynéhány volt, és a múlt század harmincas évekbeli nagy válsága idején is valamivel nyolcvan felett. Mit vetít ez előre a kilábalást illetően? Lehet-e következtetni a múltból a jövőre, vagy minden szempontból rendkívüli helyzetet élünk át?

A helyzet valóban rendkívüli, mert a mostani válság, szemben a 2007-2009 közöttivel, tényleg globális. A jelentősebb gazdasági hatalmak, térségek közül talán Kína az, amelyik, bár ütemcsökkenéssel, de nem negatív számokkal ússza meg a 2020-as évet, az összes többiről pedig mínusz négy és mínusz tíz százalék közötti elemzői előrejelzések olvashatók jelenleg, amikor ebben a szeptember végi időpontban már látni kellene az évet, de még mindig mozognak a számok. Ami roppant érdekes: ez szinkron jellegü válság, de nem szimmetrikus. Szinkron, hiszen napok, hetek kérdése volt csak, hogy mikor jelent meg a vírus egy társadalomban: 2019 decemberének legvégén vagy 2020. március elején, lényegében ezek voltak a globális eltérések. Ennyiben tehát valóban példa nélküli szinkronitással állt be a válság, amely azonban mégsem szimmetrikus, mert a társadalmak eltérő szituációban élik meg azt.

\section{Mi következik mindebböl?}

Először is, nagyon nehéz bármit előrelátni. A 2007-2009 közötti, hasonlóan mély, de rövidnek bizonyuló visszaeséshez képest nagy különbség, hogy most tartósan megnőtt és fennmaradt a bizonytalanság szintje. Annak idején a bizonytalanság szintje a Lehman Brothers eset után ugyan megugrott, de mivel a krízis a pénzügyi szektorból indult ki, tudhattuk, hogy a gazdaságpolitikai reagálás is alapvetően pénzügyi típusú lesz, és erre vannak régi, bevált, valamint új, ígéretes eszközök. Most azonban általános bizonytalanság uralkodik, két vonatkozásban is.

Ami a bizonytalanságok másik forrása, hogy valószínüleg a viselkedési minták is tartósan megváltoznak.

Az egyik a beszélgetésünk időpontjában még mindig vitatott ügy: vajon maga a 2020-as recesszió hogyan fut le. Átnéztem a különböző előrejelzéseket, a Valutaalapét, az OECDét, a hitelminősítőkét. Ezek között is nagyok az eltérések még úgy is, hogy a GDP-re, az inflációra, munkanélküliségre, ipari termelésre, tehát aggregált mutatókra vonatkoznak. Ami viszont a bizonytalanságok másik forrása, hogy valószínűleg a viselkedési minták is tartósan megváltoznak. Ennek a következményeit pedig nem tudjuk levezetni az eddigi trendekből. Csak egy példa: a kézfogás, a mely évszázadok óta az emberi érintkezésnek egy bevett civilizációs viselkedési formája volt, lehet, hogy most megy ki a divatból, esetleg úgy, mint a kézcsók Nyugat-Európában a XX. században. Mindezen bizonytalanságok miatt, amiről most beszélünk, részben alátámasztható korábbi válságlefutásokból, ökonometriai elemzésekből, szakértői becslésekből fakadó tudásunkkal, ugyanakkor őszintén 
be kell vallanunk, hogy olyan nagymértékủ és összetett bizonytalanság vetül rá ezekre a kalkulációkra, hogy ha majd esetleg másfél év múlva visszatekintünk a mostani beszélgetésünkre, a mai megállapításaink akár naiv eszmefuttatásnak tủnhetnek.

Annyi azért kijelenthető, hogy nem globális kilábalás várható, hanem országonként is jócskán eltérő lehet az egyes gazdaságok íve?

Igen, mint arra már utaltam is, valójában aszimmetrikus a sokk, még ha formailag szimmetrikusnak is tűnik, amennyiben mindenhol leállt a nemzetközi közlekedés, az emberek mozgása. Ám ennek a hatása más ott, ahol a tömegturizmus jelentős, és hatalmas mértékben megsínyli ezt a leállást, míg például a mezőgazdasági termelési folyamat a válságtól jórészt mentes maradt, a klímától viszont nem, és a gépiparnak az erősen automatizált részét sem érinti - legalábbis termelési oldalról. Fogyasztói oldalról viszont annál inkább kihathat a „nagy leállás”. Ez ismét felveti, hogy menyire nem látjuk elöre, milyen társadalomban fogunk élni ezután. Hiszen még azt az egyszerünek tűnő kérdést sem tudja eldönteni az általam átnézett szakanyag, hogy középtávon az automobilizációt gyorsítja vagy lassítja-e a krízis. Ha arra gondolunk, hogy a tömegközlekedéstől, a távolsági repüléstől jelenleg ódzkodnak az emberek, akkor mégis kell autó, sőt a modern, „zöld” autók vásárlása fellendül majd, akkor az autóipar köszöni szépen, technológiailag ugyan átvált, de a piacait nem veszti el. Mások viszont azt mondják, hogy a közös autóhasználat és a városon belüli autómentes közlekedés elterjedése, az életmódváltás miatt nem fogunk annyit magánautózni, ezért az elmúlt évtizedekre jellemző keresleti trendnek vége. Lám, még egy ilyen egyszerűnek tűnő kérdésre sincs magabiztos válasz. Azt hiszem, ilyen méretủ bizonytalanság békeidőben még nem leselkedett az emberiségre.

2007 után a fejlett társadalmak kétféleképpen reagáltak: Amerika a quantitative easing, a mennyiségi könnyítés politikájával, Európa pedig a német minta alapján szigorú államháztartási fegyelemmel. Most csak a bizonytalanság vehető biztosra?

Azért csupán az utólagos visszatekintés rajzol ki ilyen világos válaszokat a hitelválságra. 2008, de még 2009 és 2010 is a próbálkozások, tapogatózások kora volt. A német szigort megelőzte az, hogy 2008-ban lazítással, a kamatlábak leszállításával, állami költekezéssel, „roncsautó-programmal” reagáltak. Majd amikor az adóssághegy elkezdett emelkedni, akkor kerekedett felül az európai gondolkodásban a szigorítás 2010-ben, ami viszont az európai perifériának a más helyzetben lévő országait aszimmetrikus sokként érte. Az államháztartási fegyelmet relatíve könnyủ volt német viszonyok között megvalósítani. Meg is tették a mögöttünk hagyott évtized során. Ezért most, 2020-ban előnyös költségvetési helyzetben érte őket ez a teljesen váratlan válság. Hasonló fiskális rendbetételt az EU peremén hol sikerült elérni, hol nem. A mából visszatekintve elmosódhat az improvizálás. Mindenesetre most is azt láttam, hogy a döntéshozók a legkülönbözőbb megoldásokkal élnek, mert 2020 tavaszán nem tudtak egyértelmű választ adni: vajon egyszeri gazdasági visszaesésről van szó? V alakú a válsággörbe, gyors visszapattanással? Tavasszal ezzel volt tele a szaksajtó. Ha ez lesz a helyzet, akkor viszonylag egyszerű a dolog. Meg kell őrizni a munkahelyeket, mert úgyis visszaáll a kereslet, csak nem szabad megengedni, hogy addig szétessenek a kialakult piaci cégstruktúrák - ez a „kurzarbeit” logikája. Az amerikai vezetés a likviditásbővítésen túl - egy konzervatív kormányhoz képest egész meglepő módon - pénzszétterítéssel inkább az aggregált keresletet próbálta megtartani, számítva arra, hogy ez az átmeneti időszak nem lesz túl hosszú.

\section{Az a $\mathrm{V}$ pillanatnyilag legalábbis U-nak néz ki...}

Igen, így szeptember végén én azt látom, hogy az elemzők nagy többsége már régen nem beszél V alakról, visszapattanásról, mert ez azt feltételezné, hogy ami megzavarta a folyamatokat, az elmúlik véglegesen, és a korábbiakhoz többé-kevésbé hasonlító struktúrákban folyik tovább a világ. Most inkább úgy néz ki, hogy a vírusnak a járványügyi hatásait a hatóságok és a gyógyszergyárak nagy erőfeszítések révén talán vissza tudják szorítani, de a továbbiaknál mégis többféle szcenárióval kell számolni. Most egy biológiai vírus állította az életünket ilyen helyzet elé. De mi van, ha mondjuk, egy átfogó kibertámadást követően egy hétre leállna az internet? A gyerekek nem találnának haza az utcasarokról, mert elszoktak attól, hogy megnézzék az utcakiírást, a cégek nem tudnának távmunkát se végeztetni, és még nem is vettem sorra a drasztikusabb hatásokat. Az ilyen típusú kockázatokkal eddig csak a dús fantáziájú elemzők számoltak, mostantól azonban ezeket számba kell venni.

Említette Amerikát, ahol most néhány hét alatt hajtottak végre egy olyan mértékü - 3000 milliárd dolláros - mennyiségi könnyítést, mint a 2009 utáni teljes idöszakban, ám egyelőre nem látszanak ennek az eredményei.A munkanélküliség tavasszal hetvenéves rekordon volt, és azóta sem csökkent meghatározó mértékben.Ez nyilván kihat a fogyasztásra is, ami a tengerentúli gazdasági növekedés motorja.Közben az államadósság már a GDP száz százalékát is meghaladja.Kinőheti-e magát az amerikai gazdaság a világgazdaság húzóerejévé, mint a hitelválságot követően?

Az amerikai eset azért roppant érdekes, mert ugyan a subprime válság onnan indult ki, de az ország sokkal gyorsabban és kisebb megrázkódtatással vészelte át, mint mondjuk a kicsit lomhább és fragmentáltabb Európa.

Amerika, az egykori „korlátlan lehetőségek” világa, mostanra érett ország lett, a maga belső problémáival.

Éppen a munkaerőpiacának a dinamizmusa miatt is, ezért most is lehetséges a munkakínálat gyors alkalmazkodása. Ám jelenleg nagyon sok kérdőjel kötődik az amerikai társadalomhoz. Ha csak a 2020. tavaszi nagy leállást nézzük, azt látjuk, hogy az amerikai társadalom néhány foglalkozási és jövedelmi kategóriáját alig érintette, de közben a társadalom másik, jelentős részét keményen sújtotta. Nem tartom véletlennek, hogy a szocializmus szót, ami Amerikában szalonképtelen volt évtizedekig, most büszkén vállalják és használják magukra 
egyes politikusok. Azokat a képzeteinket, hogy az amerikai munkaerőpiac nagyon dinamikus, és ha felfut is gyorsan a munkanélküliség, de a hatékony munkaeröpiacon az álláskeresők heteken belül el tudnak helyezkedni, egyre óvatosabban kell kezelnünk. Ha nincs meg az IT-képesség, a digitalizáltság magas foka, a szélessáv - és ne gondoljuk, hogy ez Amerikában mindenhol megvan -, máris nehézkesebbé válnak a folyamatok. Amerika, az egykori „korlátlan lehetőségek” világa, valamikori frontier ország, mostanra érett ország lett, a maga belső problémáival, mint mondjuk Olaszországé a mezzogiorno, vagy volt korábban a Ruhr-vidék a németeknél. Amerikának is megvan mindez, úgy hívják, hogy Chicago, Detroit, Ohio. Ezért is van az, hogy tavasz óta a hitelminősítők, az IMF, a kutatóintézetek az amerikai gazdaságra vonatkozó feltételezéseiket egyre lejjebb viszik, és a kilábalási szakaszt is egyre hosszabbra teszik. A társadalmi struktúrákat megrengette az elmúlt és a mostani krízis. Mind kevésbé gondolom, hogy az amerikai gazdaság a világgazdaság lokomotívja lehet.

\section{Akkor majd jön Kína?}

Kínáról kevesebbet tudunk. Látszólag ott kisebb a mikroszintű bizonytalanság, mert erőteljes az állam. Azonban a történelmi tapasztalat az, hogy ha kisebb a mikroszintű bizonytalanság, és gyengébbek a visszacsatolások, vagyis a társadalom nem tud reagálni a kihívásokra a maga zavaros vagy inkább változatos módján, merthogy le van szabályozva, akkor könnyen megroppanhat bármely belső politikai ok miatt. Ezért tehát a Kínával kapcsolatos dilemmáink nem is annyira gazdaságiak, jóllehet a middle income trap, a közepes fejlettség csapda fogalma pontosan Kína kapcsán került be a szakirodalomba.Vagyis amikor egy ország már nem eléggé szegény ahhoz, hogy olcsó legyen, nagy megtakarítási képességgel, ahol az emberek hatalmas önfeláldozással dolgoznak, de nem is elég gazdag ahhoz, hogy az intézményei tartósak, erősek, teherbírók legyenek, és az élet hullámzásait kellő tartalékkal át tudják vészelni. Kína e két állapot között van. Feltételezem, hogy törékeny a belső helyzete is, és az a külső erőfitogtatás, amit a kínai kormány most már több szomszédjával szemben is megenged magának, lehet a gyengeség jele is. Én mint közgazdász itt meg kell, hogy álljak, de az régi tapasztalat, hogy ha egy hosszú-hosszú töretlen növekedési szakasz után bármi törés jön, ott olyan feszültségek tudnak keletkezni, amelyeknek a társadalmi mozgásformáit nem tudjuk elörejelezni. Ezért azt gondolom, hogy Kína nem lesz a glóbusznak olyan értelemben a lokomotívja, mint eddig.

\section{Melyek lesznek így a gazdasági erőközpontok?}

Azokról az értékláncokról, amelyekbe szerveződik a termelés, elmondható, hogy globálisak. De elég sok felmérés azt mutatja, hogy bár egy modern termékhez kell pár ezer alkatrész, amit akár több tucat országból szereznek be, azért a műveletek többsége alapvetően regionális. Láttam olyan tanulmányt, amely szerint a francia cégek a termelési lánc elemeinek zömét a tágan vett Európából szerzik be, akkor is, ha globális a termék, és jelenleg mindegyik földrészről vannak beszállítók. Azoknak jelentős része azonban helyettesíthető. Amiből nem tudnának kilépni a franciák, és ez igaz ránk is, az a regionális beágyazottság, az európai gazdasági tér. Ezért azt gondolom, hogy az elkövetkezőkben nem az említett két nagy ország fogja magával húzni a többit, hanem a régióknak a jelentősége nő meg még inkább. Még egy nagy országon belül is lesznek olyan területek, amelyek prosperálnak, és lesznek olyanok, amelyek nem tudnak bekapcsolódni ezekbe az új játékszabályok szerint működő gazdaságokba.

Hogyan lehet kiegyenlíteni az ebből adódó feszültségeket egy adott társadalmon belül?

Nincs mit csinálni, szolidaritási kereteket kell alakítani, országokon belül, országok között, jövedelmi transzferekkel. Most újra megjelentek a nemzeti piacvédelem lejárt szavatosságú gondolatával házalók, akik a termelés egészét vissza akarják vinné nemzeti szintre. Erről hamar kiderülne, hogy zsákutca. Az önellátás igen rövid távú megoldásnak elmegy, középés hosszú távúnak azonban nagyon rossz, ezért nem is tartható fenn.

A világkereskedelem idén mintegy 15 százalékosra várt visszaesésével megroppant az a modell is, hogy a növekvő amerikai eladósodást Kína vásárolja fel. Mi lesz a dollárral?

Valóban érdekes aránytalanság áll fenn.Az Egyesült Âllamok a világ GDP-jének a 15-16 százalékát adja, attól függően, hogyan számítjuk át az országok outputját; a világkereskedelemnek pedig úgy egytizedét. Amerika tehát országként nagy, kereskedőként szintén elég nagy. Ám a dollár ehhez képest egyszerűen óriás, hegemón szerepben van. A globális értékpapír-kibocsátás hetven százalékát adja, a külkereskedelmi tranzakciók lebonyolításában az amerikai dollár szerepe kétharmad körüli, számos ország köti hozzá az árfolyamát. A dollár az ország valós gazdasági súlya felett van reprezentálva a pénzvilágban. Az euró némileg elmarad az európai gazdaság súlyától, de erős második. És vannak olyan országok, amelyeknek a pénzügyi súlya kisebb, mint ami logikus volna. Valószínű, hogy a következő évek folyamatai, köztük a regionalizmus, amiről már szó volt, fel fogiák erősíteni a valutarégióknak a fontosságát, szerepét. Ebből adódik, hogy a dollár részaránya idővel süllyedni fog. Gyanítom, hogy az az erőfeszítés, amit az európai vezetők az euró szerepének erősítése érdekében tettek, eredményekre vezet, olyan formában is, hogy bővül az eurózóna. Kis mértékben ugyan, hiszen a horvát és bolgár gazdaság, vagy a nyomukban Románia nem hatalmas tétel nemzetközileg, de a bővülés folytatódik. Még fontosabb talán, hogy bizonyos iparágak euróizálódnak, áttérnek más valutákról, elsősorban a fontról, a dollárról, talán a svájci frankról is. Nem szükségszerü, hogy az olajkereskedelem dollárban legyen, ha mondjuk, a gázkereskedelmet euróban számlázzák.

Azt hiszem, hogy ezen a téren beindulnak a folyamatok, és nemcsak külpolitikai okok miatt, hanem a világkereskedelem aránymódosulásait követve. Főleg akkor, ha bizonyos kulcsiparágakban az európai, a kínai és egyéb szereplők belépnek olyan piacokra, amelyeket most a nagy amerikai cégek egyedül uralnak. 
Eddig arról beszéltünk, hogy milyen bizonytalan a reálgazdaság, és mennyire nem tudunk határozott kijelentéseket tenni. De úgy tünik, mintha a pénzpiacok minderről nem vennének tudomást, és sokkal jobban elszakadnának a reálgazdasági alapoktól, mint korábban bármikor. Mindez a technológiai cégek növekvő tőzsdei súlyával magyarázható?

Valóban, lehet annak tőzsdei következménye, hogy a technológiai cégek a járványválságot nem hátrányként élik meg. A történelmi tapasztalatok alapján minden válság felgyorsítja azokat a folyamatokat, amelyek már megindultak, lehetségessé váltak, de a korábbi korszak kötöttségei miatt addig lassabban haladtak. A háborúk is véget szoktak vetni a korábbi kötöttségeknek, és katapultálják a társadalmakat egy új helyzetbe, amelyben az új technológiák gyorsabban tudnak elterjedni. Jelenleg a digitalizáció már teljesen átszőtte életünket, 2021-től pedig oly mértékben válik realitássá, amennyivel korábban csak a hosszú távú forgatókönyvek számoltak. Elég akár csak a magyar oktatásra gondolni, ahol kényszerből három nap alatt éveket kellett előreugraniuk a magyar iskoláknak és családoknak. Ezt többé-kevésbé meg is tették, persze társadalmilag nagy szórással.

A történelmi tapasztalatok alapján minden válság felgyorsítja azokat a folyamatokat, amelyek már megindultak.

A technológiai cégeknél az alapmutatók is jók lesznek, tehát ott nem látszik nagy szakadás a teljesítmény és az árfolyam között. Az, hogy mindez kiterjed-e más cégekre is, amelyeknél azután majd korrekció válik szükségessé, persze már egészen más kérdés. Egyelőre annak hatása érződik a pénzpiacokon,hogy a hatóságok a jól bevált pénzszaporítási módszerhez nyúltak, mint az öreg tábornokok, akik az új háborút a korábbi, bevált eszközökkel akarják megvívni. Az államok a költségvetési hiányaikat elengedték, a jegybankok pedig leviszik vagy alacsonyan tartják a kamatokat, és egyéb eszközökkel is pumpálják a pénzt. A pénzügyi aktíváknak az elszakadása a reálgazdaságtól így nem meglepő, az már nagyobb kérdés, hogy meddig tarthat, és mi jön utána. Mert ha tartós japánizálódás áll be a nyugati országokban, vagyis nem nő a gazdaság, és megtakarítanak az emberek, óvatosságból vigyáznak magukra meg a környezetükre, akkor nem várható a kamatszint megemelkedése, és így jó ideig folytatódnak a mai átmeneti viszonyok. De ez nem szükségszerü. Akkor viszont felmerül a fenntarthatóság kérdése, mint 2008 után, amire 2010-ben a németek és a hollandok az austerity-vel, megszorításokkal válaszoltak. Valószínű, hogy a 2020-as évek elején fokozatosan vagy hirtelen, ezt most nem lehet látni, de be kell következnie egy normalizálódásnak.

\section{Ez mit is jelent pontosabban?}

A kamatok fel, a tőzsdeindexek le. Mert most fordítva van. De ebben az egész történetben olyan sok „ha” van, hogy mindez nem elörejelzés, hanem szcenárióképzés.
Mindenesetre a technológiai cégekkel együtt a pénzügyi szolgáltatók is jobban jöttek ki eddig a válságból, mint azt még tavasszal gondolni lehetett. E területeken is megalapozott a további óvatos optimizmus?

A szolgáltatási szektor egésze nagyon sokat szenvedett a Covidtól, a tömegturizmust például tönkretette. Ahol azonban az emberi érintkezés csekély kockázattal jár, vagy pedig az ügylet közvetíthető online módon, ott lényegében nem voltak üzemleállási problémák. A pénzügyi szektor folyamatai megnyugtatónak bizonyultak, a digitalizáció újabb lökést kapott. Azok az ágazatok, amelyek tudtak digitalizálni - ilyen a bankszektor és a biztosítások jelentős része, a back office mindenképpen - a mesterséges intelligencia révén már most komoly elörehaladást értek el a költséghatékonyság, a megtakarítások és a minőségstabilizálás terén. Jelentős irodalma van annak, hogy nemcsak azért automatizálnak a cégek, mert olcsóbbá válnak a folyamatok, hanem mert egyben a kiszámíthatóságuk is jobb lesz. Nem betegszik meg, nem sztrájkol a gép, és miközben az embercsoportok közötti kultúrák különbsége, az időzónák léte is tranzakciós költséget generáló ügy, addig az összekapcsolt gépeknél, technológiáknál ilyen nincs. Ezért azt gondolom, hogy bizonyos iparágakban - és a pénzügyi szolgáltatások is ilyenek - a krízis inkább csak a felgyorsítás miatt okozott zavarokat, de nem fog rossz évnek számítani.

A biztosításokat illetően pedig le lehet porolni a régi szlogent: Biztosítás - biztonság?

Ha azzal kezdődött a beszélgetés, hogy a 2020-tól megnyíló korszaknak - mert ez korszak lesz, itt lezárult valami - a központi szava a bizonytalanság, nem pedig a kockázat, ami mérhető és beárazható, akkor minden tényezőnek, ami a bizonytalanságot kockázattá transzformálja, tehát már kalibrálható nem-tudássá, a társadalmi hasznossága és súlya nőni fog. Annak köszönhetően, hogy új helyzet van, és sem a döntéshozók, sem a vállalatok, sem a családok nem tudják, hogy mit hozhat az élet, a kockázatoknak a terítése, szétosztása és kezelése fontosabbá válik, mint amikor maga az alapfolyamat trendet követ. Most nincs trend, legalábbis a beszélgetés időpontjában nem látjuk. Látjuk viszont az elágazásoknak a nagy számát. Csak feltételezzük, hogy ha ezen az időszakon túljutunk, akkor lesz egy „new normal”, egy új igazodási keret, amihez hozzászokunk, és amin belül működünk. A nagymértékű bizonytalanság felértékeli például a biztosítást is mint emberi tevékenységet. Lesznek új kockázatok is: a már említett kiberkockázat nőni fog, ahogy az életünk és az üzletünk is egyre jobban függ a digitális eszközöktől. Ez ellen is kell valamifajta védelmet szereznünk, akár az olyan nem katasztrofális, de lényegi ügyre is, mint az adatvesztés. Az adat olyan termelési tényezővé vált, amit be kell biztosítani. Az ilyen típusú újfajta kockázatokat is lehet teríteni, viszontbiztosítással alátámasztani. Egyszerűen logikai alapon is azt gondolja az ember, hogy ha a digitalizáció ennyire meghatározó elemévé válik az életünknek, akkor azok a szakmai tevékenységek, amelyek ezeket a bizonytalanságokat képesek transzformálni kockázatokká, nagyon fontosak, és mint ilyenek, sikeresek is lesznek. 